\title{
Functional group composition of organic aerosol from combustion emissions and secondary processes at two contrasted urban environments ${ }^{\text {方 }}$
}

\author{
Imad El Haddad ${ }^{\mathrm{a}, \mathrm{b}, \mathrm{e}, *}$, Nicolas Marchand ${ }^{\mathrm{a}, \mathrm{b}, * *}$, Barbara D’Anna ${ }^{\mathrm{c}}$, Jean Luc Jaffrezo ${ }^{\mathrm{d}}$, \\ Henri Wortham ${ }^{\mathrm{a}, \mathrm{b}}$ \\ a Aix-Marseille Univ, Laboratoire Chimie Environnement, 13331 Marseille Cedex 03, France \\ ${ }^{\mathrm{b}}$ CNRS, FRE 3416, 13331 Marseille Cedex 03, France \\ ${ }^{c}$ Université de Lyon 1/CNRS, UMR5256, IRCELYON, Institut de Recherches sur la Catalyse et l'Environnement de Lyon, Villeurbanne, France \\ d Université Joseph Fourier-Grenoble 1-CNRS, UMR 5183, Laboratoire de Glaciologie et Géophysique de l'Environnement, Saint Martin d'Hères 38402, France \\ ${ }^{\mathrm{e}}$ Paul Scherrer Institut (PSI), Laboratory of Atmospheric Chemistry, 5232 Villigen PSI, Switzerland.
}

\section{H I G H L I G H T S}

- Tandem mass spectrometry is used to characterize functional groups in primary and secondary OA.

- Aging increases by one order of magnitude carboxylic and carbonyl functional groups.

- Biomass burning OA and SOA are associated with substantial amounts of alcohol functional groups.

\section{A R T I C L E I N F O}

\section{Article history:}

Received 5 July 2012

Received in revised form

13 February 2013

Accepted 8 April 2013

\section{Keywords}

Oxygenated functional groups

Primary organic aerosol

Secondary organic aerosol

Photochemical aging

Van Krevelen diagram

\begin{abstract}
A B S T R A C T
The quantification of major functional groups in atmospheric organic aerosol (OA) provides a constraint on the types of compounds emitted and formed in atmospheric conditions. This paper presents functional group composition of organic aerosol from two contrasted urban environments: Marseille during summer and Grenoble during winter. Functional groups were determined using a tandem mass spectrometry approach, enabling the quantification of carboxylic $(\mathrm{RCOOH})$, carbonyl $\left(\mathrm{RCOR}^{\prime}\right)$, and nitro $\left(\mathrm{RNO}_{2}\right)$ functional groups. Using a multiple regression analysis, absolute concentrations of functional groups were combined with those of organic carbon derived from different sources in order to infer the functional group contents of different organic aerosol fractions. These fractions include fossil fuel combustion emissions, biomass burning emissions and secondary organic aerosol (SOA). Results clearly highlight the differences between functional group fingerprints of primary and secondary OA fractions. OA emitted from primary sources is found to be moderately functionalized, as about 20 carbons per 1000 bear one of the functional groups determined here, whereas SOA is much more functionalized, as in average 94 carbons per 1000 bear a functional group under study. Aging processes appear to increase both $\mathrm{RCOOH}$ and $\mathrm{RCOR}^{\prime}$ functional group contents by nearly one order of magnitude. Conversely, $\mathrm{RNO}_{2}$ content is found to decrease with photochemical processes. Finally, our results also suggest that other functional groups significantly contribute to biomass smoke and SOA. In particular, for SOA, the overall oxygen content, assessed using aerosol mass spectrometer measurements by an $0: C$ ratio of 0.63 , is significantly higher than the apparent $\mathrm{O}: \mathrm{C}^{*}$ ratio of 0.17 estimated based on functional groups measured here. A thorough examination of our data suggests that this remaining unexplained oxygen content can be most probably assigned to alcohol $(\mathrm{ROH})$, organic peroxides $(\mathrm{ROOH})$, organonitrates $\left(\mathrm{RONO}_{2}\right)$ and/or organosulfates $\left(\mathrm{ROSO}_{3} \mathrm{H}\right)$.
\end{abstract}

(c) 2013 Elsevier Ltd. All rights reserved.

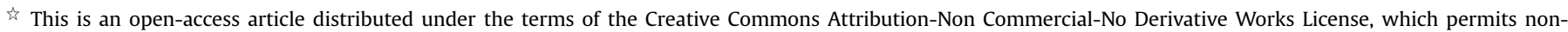
commercial use, distribution, and reproduction in any medium, provided the original author and source are credited.

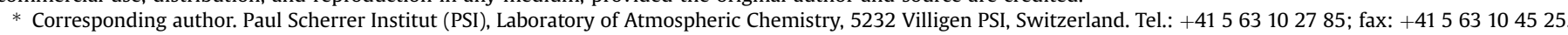

** Corresponding author. Aix-Marseille Univ, Laboratoire Chimie Environnement, 13331 Marseille Cedex 03 , France. Tel.: +33 413551051 ; fax: +33 413551060. E-mail addresses: imad.el-haddad@psi.ch (I. El Haddad), Nicolas.Marchand@univ-amu.fr (N. Marchand).
} 


\section{Introduction}

There has been strong interest of late in the organic fraction of the atmospheric aerosol (OA), particularly its complex composition, oxidation state, and reactivity (Hallquist et al., 2009 and reference therein), properties that govern its health and climate impacts. Recent developments of isotopic $\left({ }^{14} \mathrm{C}\right)$ and real-time aerosol mass spectrometry (e.g. Aerodyne Aerosol Mass Spectrometer, AMS), together with updated inventories of molecular markers, have markedly improved our ability to identify different components of $\mathrm{OA}$ including its primary fraction (POA) directly emitted from fossil fuel combustion (PfOA) or biomass burning (BBOA) and its secondary fraction (SOA) formed in-situ in the atmosphere (Hallquist et al., 2009). While it was shown that highly oxygenated organic aerosol (OOA) constitutes the overwhelming fraction of $\mathrm{OA}$ in nearly all environments (Jimenez et al., 2009), considerable uncertainties remain in identifying the most significant routes by which this fraction accumulates and evolves in the atmosphere (Kroll and Seinfeld, 2008).

A widespread source of OOA is SOA, whose formation implicates complex oxidative processes of a myriad of volatile organic compounds (VOC), processes that include both functionalisation and fragmentation of the parent carbon backbone. As a result, an immensely complex matrix of organic compounds is formed, which remain dynamic through reversible partitioning and ongoing photochemical aging (Donahue et al., 2009; Kroll et al., 2009). Despite the complexity of the detailed molecular mechanism of SOA formation and aging, a relatively small number of functional groups characterize the oxidized molecules constituting SOA. That is, given the carbon number and the set of functional groups (Kroll et al., 2009), the physicochemical properties of SOA components including their volatility and oxidation state can be estimated and used for the development of predictive models for SOA production rates, burden, sinks and interaction with climate (e.g. Valorso et al., 2011). Ambient AMS measurements suggest that the chemical composition of SOA is characterized amongst functional groups by both carbonyls (traced by the fragment at $\mathrm{m} / \mathrm{z} 43$ ) and carboxylic acids (traced by the fragment at $m / z 44$ ), the latter predominating in aged air masses (Ng et al., 2010). More recently, the application of Van Krevelen diagrams ( $\mathrm{H}: \mathrm{C}$ vs. O:C ratio) to HR-ToF-AMS data (High Resolution-Time of Flight-Aerosol Mass Spectrometer) points out that aging seems to be in line with the formation of carboxylic (Heald et al., 2010), hydroxylic and peroxylic groups (Ng et al., 2011; Chhabra et al., 2011). While AMS results seem to be consistent with the detection of poly-carboxylic acids in OA (often referred to as HULIS for HUmic Llke Substances), the observations needed to confirm the functional group composition proposed for SOA remain currently elusive.

Because functional groups have more chemical specificity than that in $m / z$ fragments or atomic O:C ratios provided by AMS, their relative contributions (termed functionalisation rates, RF) are valuable information to investigate the possible SOA formation and evolution pathways in the atmosphere. While common analytical techniques for functional group analysis include Fourier-Transform InfraRed spectroscopy (FTIR, Liu et al., 2009; Schwartz et al., 2010; Russell et al., 2011) and nuclear magnetic resonance (NMR, Tagliavini et al., 2006; Decesari et al., 2007), we recently proposed a tandem mass spectrometry (MS/MS) approach for the quantitative analysis of carboxylic $(\mathrm{RCOOH})$, carbonyl $\left(\mathrm{RCOR}^{\prime}\right)$, and nitro $\left(\mathrm{RNO}_{2}\right)$ functional groups, with high sensitivity and good accuracy (Dron et al., 2007, 2008a,b). The application of this approach on OA emitted from different sources has revealed significant differences in their functional group contents (Dron et al., 2010). It was shown that laboratory generated SOA produced through photo-oxidation of o-xylene is dominated by RCOR', whereas RCOOH and $\mathrm{RNO}_{2}$ are comparatively preponderant in wood smoke and vehicular emissions, respectively. It was hence suggested that these functional group fingerprints offer an interesting potential to discriminate the dominant sources of ambient organic aerosol and its chemical evolution in the atmosphere. More recently, the same approach has been applied to examine the impact of aging on genuine HULIS, clearly showing that such processes increase significantly the oxidation state of the organic matter (Baduel et al., 2011). Here, we present results of functional group analyses in two contrasted urban environments (Marseille in the summer and Grenoble in the winter), with the aim of characterising the functional group fingerprints of $\mathrm{OA}$ arising from different sources in real ambient conditions and assessing the impact of photochemistry on these fingerprints.

\section{Methods}

\section{1. $P M_{2.5}$ collection and characterisation}

Results presented below were obtained within the two intensive field campaigns of the FORMES project at two contrasted urban environments in France, Marseille in summer (31 June-14 July 2008) and Grenoble in winter (14-29 January 2009). A full description of the sampling sites and the general conditions encountered can be found in El Haddad et al. (2011a,b) and Favez et al. (2010), for Marseille and Grenoble campaigns, respectively.

For both campaigns, particles were continuously collected on a 12 h-basis using high volume samplers (Digitel, DA80) operating at a flow rate of $30 \mathrm{~m}^{3} \mathrm{~h}^{-1}$. The collection took place onto $150 \mathrm{~mm}$ diameter quartz fibre filters (Whatman QMA), pre-heated at $500{ }^{\circ} \mathrm{C}$ during $3 \mathrm{~h}$ (30 samples for Marseille and 30 samples for Grenoble). Samples were then stored at $-18{ }^{\circ} \mathrm{C}$ in aluminium foil, sealed in polyethylene bags until analysis. Six field blank samples were also prepared following the same procedure.

The collected aerosol was comprehensively characterised, and data are thoroughly presented and discussed in El Haddad et al. (2011a,b) and Favez et al. (2010), for Marseille and Grenoble campaigns, respectively. In particular, data used in this study comprise concentrations of EC and OC, analysed using the thermo-optical transmission method with a Sunset Lab analyzer and following EUSAAR2 temperature program proposed by Cavalli et al. (2010).

The same samples were characterised for the functional group content of the organic carbon, $\mathrm{FG}\left[\mathrm{nmol} \mathrm{m}^{-3}\right]$. As fully presented in Appendix A, functional group analysis was performed by atmospheric pressure chemical ionization (APCI)-tandem mass spectrometry. This technique is based on the ability of the carboxylic $(\mathrm{RCOOH})$, carbonyl $\left(\mathrm{RCOR}^{\prime}\right)$, and nitro $\left(\mathrm{RNO}_{2}\right)$ functional groups to lose a specific neutral fragment or to produce a characteristic ion in the collision cell (Dron et al., 2007, 2008a,b, 2010). It enables the quantitative determination of these functional groups in aerosol extracts, based on the analyses of reference mixtures containing high number of compounds with various chemical structures, bearing the functional groups of interest. Method uncertainties, extraction efficiency, detection limit and sampling artefacts are detailed in Appendix A.

Normalizing the concentration of an individual functional group, FG $\left[\mathrm{nmol} \mathrm{m} \mathrm{m}^{-3}\right.$ ], by the corresponding OC molar content $\left[\mu \mathrm{mol} \mathrm{m}{ }^{-3}\right]$ gives access to the functionalisation rate $(\mathrm{RF}=\mathrm{FG} / \mathrm{OC})$, expressed in number of functions per one thousand $\mathrm{OC}[\%]$. The reciprocal ratio OC/FG represents the probability that a carbon bears the functional group of interest (Valorso et al., 2011). Finally, we define the total functionalisation rate, $\mathrm{RF}_{\text {total }}$, as the sum of individual RF determined here. 


\subsection{OC source apportionment - CMB modelling using organic markers}

Available data used here also include source contributions to organic aerosol, apportioned using a Chemical Mass Balance (CMB) analysis in conjunction with concentrations of organic markers, as fully described in El Haddad et al. (2011a,b) and Favez et al. (2010), for Marseille and Grenoble campaigns, respectively. Briefly, for both campaigns, three general OA classes can be distinguished: primary fossil fuel combustion emissions-PfOA (vehicular emissions + industrial emissions/shipping in the case of Marseille and vehicular emissions + natural gas combustion in the case of Grenoble), biomass burning smoke-BBOA and secondary sources-SOA. CMB results reflect the contrast in source contributions to the organic aerosol at the 2 environments and can be summarized as follows: In the case of Marseille (summer), $\mathrm{OA}$ is found to be largely dominated by SOA, contributing on average $78 \%$ of the total OC mass; fossil fuel combustion and biomass burning contribute to $19 \%$ and $1 \%$, respectively (El Haddad et al., 2011a). In contrast, at Grenoble, OA is governed by biomass smoke contributing $68 \%$ of the total OC mass, while fossil fuel combustion and SOA contribute to $9 \%$ and $23 \%$, respectively (Favez et al., 2010).

\subsection{AMS measurements and PMF modelling}

A compact time of flight (c-TOF, Tofwerk) Aerodyne Aerosol Mass Spectrometer (AMS) was employed at both sites, as described in detail in El Haddad et al. (2012) and Favez et al. (2010), for Marseille and Grenoble campaigns, respectively. AMS provides quantitative OA mass spectra by combining thermal vaporization and electron ionization (for more details see for e.g. Drewnick et al., 2005). Positive Matrix Factorization (PMF) of OA spectra enables differentiating several OA components (Jimenez et al., 2009), including particularly POA and SOA (OOA). OA was deconvolved into 3 components for Grenoble including traffic emissions, biomass burning and one average OOA and into 4 components for Marseille including traffic emissions, industrial emissions and 2 OOAs components comprising a low volatile highly oxidized fraction (LVOOA) and a semi-volatile less oxidized fraction (SVOOA). Following $\mathrm{Ng}$ et al. (2011) parameterisations, AMS data were used here to estimate the $\mathrm{H}: \mathrm{C}$ and $\mathrm{O}: \mathrm{C}$ ratios of OOA in Grenoble and Marseille, based on the $\mathrm{m} / \mathrm{zm} / \mathrm{z} 43$ andm/zm/z 44 signals in the OOA fractions ( $\mathrm{f} 43$ and $\mathrm{f} 44$ respectively). (Equations used: $\mathrm{H}: \mathrm{C}=1.01+6.07 \times f_{43}+6.07 \times f_{43}^{2}$; $\mathrm{O}: \mathrm{C}=0.08+3.82 \times f_{44}$ ). These estimates are then contrasted to functional group results to infer the chemical nature and the amounts of functional groups not measured here.

\section{Results and discussion}

\subsection{OA functional group content at Marseille and Grenoble}

Average molar concentrations $\left[\mathrm{nmol} \mathrm{m}^{-3}\right.$ ] of the three organic functional groups measured in the aerosol at Marseille and Grenoble are reported in Table 1 and compared with concentrations measured in other environments (Tagliavini et al., 2006; Liu et al., 2009; Stone et al., 2009). Such a comparison is not always straightforward as these concentrations are not determined using the same analytical technique (different analytical techniques give access to different types of functional groups) and does not refer in some cases to the same fraction of carbonaceous aerosol. In addition, with such techniques, where no reference approach is available, biases in the absolute concentrations are highly probable and more reliable information can be drawn by examining relative changes in the functional content of different OA types.
Table 1

Concentrations of the three functional groups $\left(\mathrm{RCOOH}, \mathrm{RCOR}\right.$ and $\left.\mathrm{RNO}_{2}\right)$ determined in the organic aerosol at Marseille and Grenoble, compared to those reported in other sites.

\begin{tabular}{|c|c|c|c|c|c|c|}
\hline Sites & $\mathrm{RCOOH}^{\mathrm{f}}$ & $\mathrm{RCOR}^{\prime \mathrm{f}}$ & $\mathrm{RNO}_{2}{ }^{\mathrm{f}}$ & $\mathrm{OC}^{\mathrm{g}}$ & WSOC $^{g}$ & Analytic method \\
\hline Marseille $^{a}$ & $19.2(52)$ & $5.9(16)$ & $0.54(1.4)$ & 4.6 & 2.4 & APCI-MS/MS \\
\hline Grenoble $^{\mathrm{a}}$ & $16.2(22)$ & $4.7(5.2)$ & $2.9(4.2)$ & 8.8 & 3.1 & APCI-MS/MS \\
\hline Chamonix $^{\mathrm{b}}$ & $36.3(20)$ & $7.6(5.0)$ & $2.0(1.6)$ & 21 & - & APCI-MS/MS \\
\hline $\begin{array}{l}\text { SIMAT Milargo } \\
\left(_{\text {(Mexico })^{c}}\right.\end{array}$ & $67(120)$ & $3.7(7.7)$ & - & 5.5 & - & FTIR \\
\hline Amazon basin ${ }^{\mathrm{d}}$ & 266 & - & - & - & 26.4 & H-NMR (WSOC) \\
\hline Riverside $^{\mathrm{e}}$ & $30(35)$ & - & - & 8.4 & 6.0 & LC APCI-MS/MS \\
\hline Atlanta $^{\mathrm{e}}$ & $4.0(6)$ & - & - & 6.7 & 2.0 & LC APCI-MS/MS \\
\hline
\end{tabular}

a This study.

b Urban site, Dron et al. (2010).

c Urban site, Liu et al. (2009).

${ }^{d}$ Forested area, Tagliavini et al. (2006).

e Urban sites, Stone et al. (2009).

f $\mathrm{nmol} \mathrm{m}^{-3}$.

g $\mu \mathrm{g} \mathrm{m}^{-3}$; between bracts are functionnalisation rates expressed in FG \% OC.

In our case and throughout the periods of measurements, all samples are found to be dominated by $\mathrm{RCOOH}$ with average concentrations of 19.2 and $16.2 \mathrm{nmol} \mathrm{m}^{-3}$ for Marseille and Grenoble, respectively. $\mathrm{RCOOH}$ concentrations fall within this range of concentrations reported in previous studies (Table 1), with average values higher than those reported in Atlanta but lower than those found during Milargo experiment (Mexico), providing some support to absolute values found here. Lower concentrations of carbonyls are measured with averages of 5.9 and $4.7 \mathrm{nmol} \mathrm{m}^{-3}$ for Marseille and Grenoble, respectively, in agreement with previous functional group results (Table 1 ). Finally, $\mathrm{RNO}_{2}$ are the least represented functional group with concentrations significantly higher in the aerosol collected in Grenoble (average concentrations of $0.54 \mathrm{nmol} \mathrm{m}^{-3}$ for Marseille and $2.9 \mathrm{nmol} \mathrm{m}^{-3}$ for Grenoble).

In order to assess and compare the functionalisation rates (RF) of the organic aerosol in Marseille and Grenoble, the functional group absolute concentrations [ $\mathrm{nmol} \mathrm{m}^{-3}$ ] are plotted in Fig. 1 against OC molar concentrations $\left[\mu \mathrm{mol} \mathrm{m} \mathrm{m}^{-3}\right]$. For comparison purposes, the functionalisation rates of organic aerosols at emission points are also shown, including xylene photo-oxidation (Dron et al., 2010), vehicular emissions (El Haddad et al., 2009; Dron et al., 2010) and genuine HULIS extracted from biomass smoke (Baduel et al., 2011). Overall, fairly good correlations between the three functional groups and OC can be noticed at each of the two sites $\left(R^{2}>0.55\right.$, $n=28$ for Marseille and $n=24$ for Grenoble), implying rather constant functionalisation rates that can be inferred from the slopes of the linear regressions. This observation is consistent with the prevalence of a single dominant source with relatively constant functionalisation rate impacting the aerosol at each of the sites (i.e. SOA in Marseille and biomass burning in Grenoble).

Now, comparing the functionalisation rates of the organic carbon in Marseille and Grenoble reveals noteworthy differences between the two environments. Average RCOOH and RCOR' functionalisation rates in Marseille are significantly higher than those observed in Grenoble (Fig. 1). In Marseille, 53\% and 16\% of the organic carbon bear a $\mathrm{RCOOH}$ and $\mathrm{RCOR}^{\prime}$ group, respectively ( 1 carbon out of 19 bears a RCOOH group and 1 carbon out of 59 bear a RCOR' group), whereas in Grenoble the same functional groups represent only $20 \%$ and $5.8 \%$ of OC, respectively ( 1 carbon out of 50 bears a RCOOH group and 1 carbon out of 170 bear a RCOR' group). High contents in oxygenated functional groups in Marseille can be assigned to the active photochemistry and high SOA proportions (El Haddad et al., 2011a,b) in this region during summertime (see for comparison the functional content of SOA components 

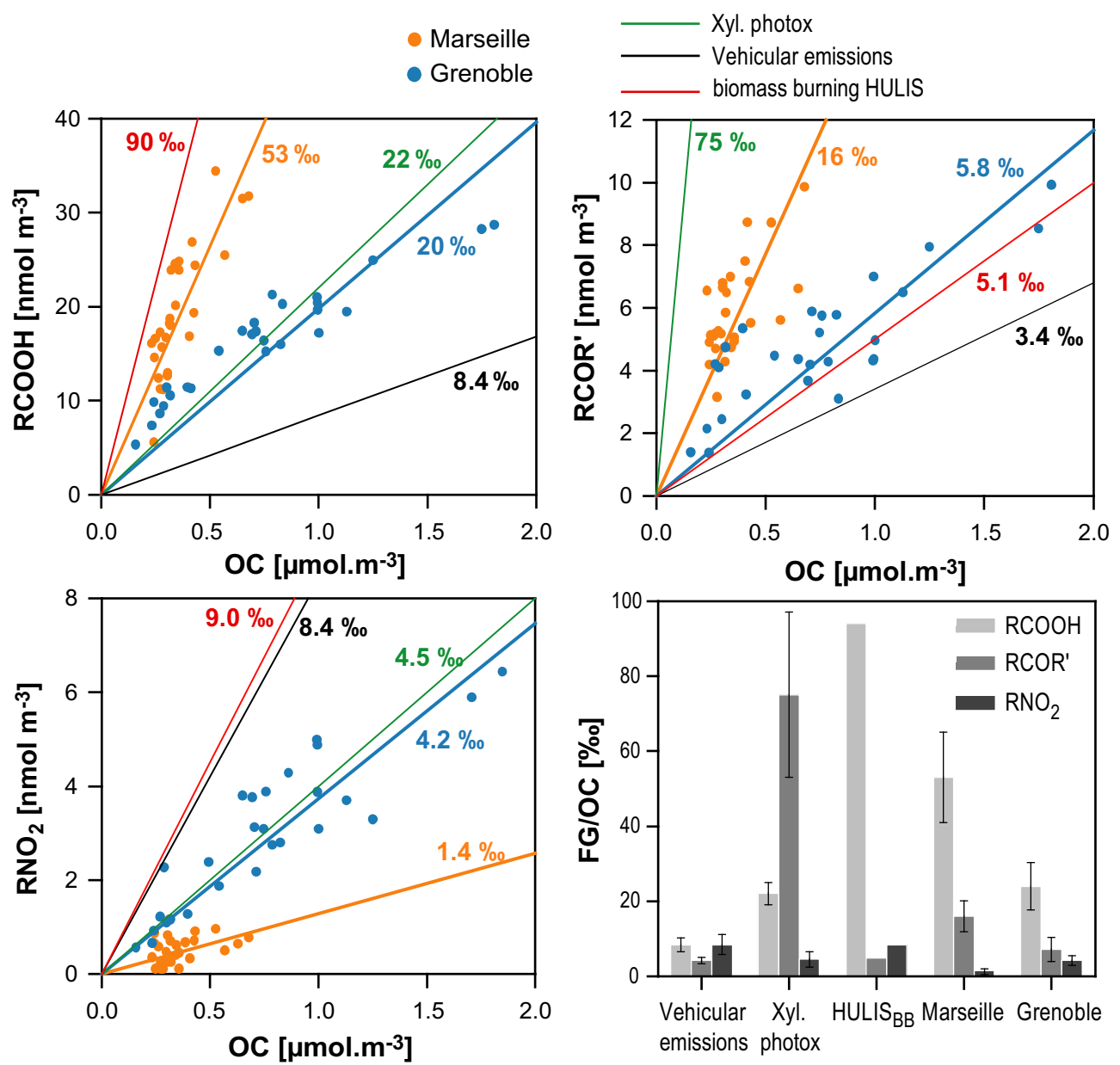

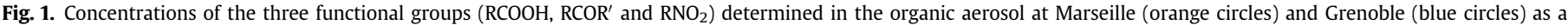

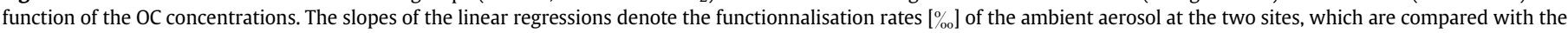

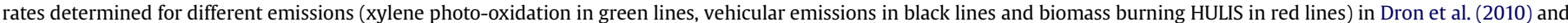

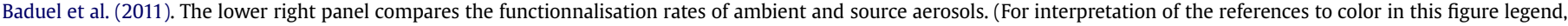
the reader is referred to the web version of this article.)

in Fig. 1, i.e. RCOOH represents $90 \%$ of OC for HULIS and RCOR' represents $75 \%$ of OC derived from xylene photo-oxidation).

Conversely, in Grenoble the organic carbon is characterised by high $\mathrm{RNO}_{2}$ content, representing 4.2 functional groups per one thousand carbon atoms, whereas in Marseille only $1.4 \%$ of the organic carbon bear a $\mathrm{RNO}_{2}$ group. This significant difference between the two environments can be most likely related to high inputs from combustion sources characterised by high $\mathrm{RNO}_{2}$ contents, in the case of Grenoble. High proportion of $\mathrm{RNO}_{2}$ in combustion emissions is well known (e.g. Heeb et al., 2008) and is illustrated in Fig. 1, where this function represents $8.4 \%$ and $9.0 \%$ of $O C$ from vehicular emissions and biomass burning HULIS, respectively. Photochemical decay of $\mathrm{RNO}_{2}$-bearing-compounds in the atmosphere is another possible explanation for its low content in the samples collected in Marseille. This hypothesis has experimentally been confirmed for atmospheric HULIS (Baduel et al., 2011).

\subsection{Link between functional group contents and emitting sources}

\subsubsection{Multiple regression analysis}

The above comparisons clearly highlight the differences in the functional group contents of organic aerosols at the two environments. In order to quantitatively determine these functionalisation rates (referred to as $\mathrm{RF}_{i}$ for functionalisation rate of $\mathrm{OA}$ derived from a considered source $i$ ), a multiple regression analysis was used. It combines measured concentrations of functional groups $\left(\mathrm{FG}_{\text {meas- }}\right.$

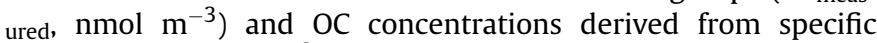
sources $\left(\mathrm{OC}_{i}, \mu \mathrm{mol} \mathrm{m}{ }^{-3}\right.$, apportioned by $\mathrm{CMB}$ as presented in Section 2.2). We seek to determine $\mathrm{RF}_{i}$ for three $\mathrm{OA}$ fractions, including fossil fuel combustion emissions-PfOA, biomass smoke-BBOA and the secondary fraction-SOA. $\mathrm{RF}_{i}$ are reported in Table 2 and employed to reconstruct in Fig. 2 the contribution from the three different sources to functional group concentrations measured at Marseille and Grenoble.

Technical details regarding the analysis are fully represented in Appendix B. Overall, it is found that the calculations are able to satisfactory achieve closure of measured FG concentrations, as illustrated in Fig. 2 (with $R^{2}>0.6$ for all FG). Some discrepancies between calculated and measured concentrations are noteworthy, particularly in the case of Marseille. These can be related, on the one hand, to the fact that analysis applied here consider a single value of $\mathrm{RF}_{i}$ for each fraction, while these can be highly variable, strongly affected by the combustion conditions by which primary aerosols are emitted (Dron et al., 2010), by the myriad of different precursors involved in SOA formation (Chhabra et al., 2011) and by the air masses photochemical age (Donahue et al., 2009). On the other hand, photochemical decay of functional groups can also impact the $\mathrm{RF}_{i}$ values of both primary and secondary fractions. This 
Table 2

Organic carbon functionalisation rates of fossil fuel combustion emissions (PfOA) biomass burning (BBOA) and SOA estimated by the multiple regression analysis. Picharts present the contribution of each functional group to the total quantified functions. Based on these rates, the probabilities (OC/FG) of a carbon to bear a $\mathrm{RCOOH}, \mathrm{RCOR}^{\prime}$ or $\mathrm{RNO}_{2}$ are calculated. Also reported are the inferred partial $\mathrm{O}: \mathrm{C}^{*}$ ratios that only refer to functional groups quantified here.

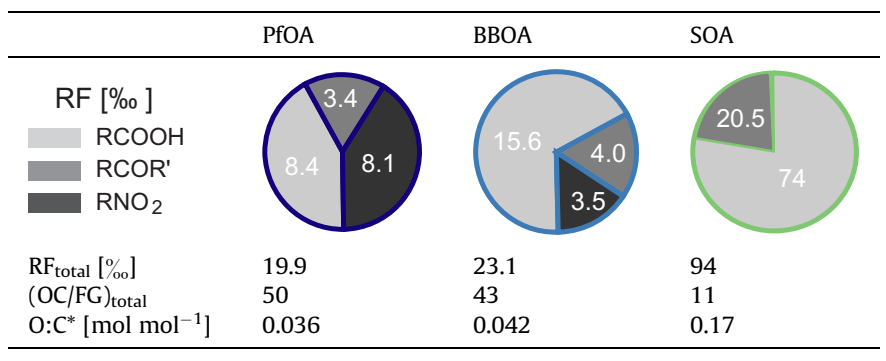

can be clearly noticed in Fig. 2 in the case of $\mathrm{RNO}_{2}$ groups, for which the regression analysis overestimates the measured summertime concentrations by a factor of 2.13, corroborating the aboveproposed assumption of $\mathrm{RNO}_{2}$ decay under ambient conditions at summer time. Such decay by photochemical aging can equally affect the other two functional groups (e.g. decarboxylation, Baduel et al., 2011 and references therein). Consequently, the increase of their $\mathrm{RF}_{i}$ values calculated for the summer period with SOA formation (Section 3.1) can only denote the net increase of the $\mathrm{RF}_{i}$ of these groups or said differently a higher steady state (i.e. formation - decay) reached for these groups. Therefore, $\mathrm{RF}_{i}$ determined here cannot fully represent the multivariate conditions encountered in the real atmosphere and hence must be regarded as average values for functionalisation rates of $\mathrm{OA}$ derived from direct emissions (PfOA and BBOA fractions) and photochemical processes (SOA fraction). The uncertainties associated with average $\mathrm{RF}_{i}$ are estimated to range between $5 \%$ and $75 \%$ (average 20\%; Table A2, Appendix B), depending on the considered functional group and $\mathrm{OA}$ fraction.

\subsubsection{Functional group content of PfOA, BBOA and SOA and impact of aging}

Table 2 reports $\mathrm{RF}_{i}$ of PfOA, BBOA and SOA estimated by the multiple regression analysis. Fig. 3 compares these rates in a 2 dimensional space ( $\mathrm{RCOR}^{\prime}$ vs. $\mathrm{RCOOH}$ colour scaled by $\mathrm{RNO}_{2}$ rates as a third dimension) with those measured for ambient aerosol in Marseille and Grenoble and at emissions (biomass burning HULIS, aged biomass burning HULIS and Xylene SOA). This diagram highlights quite readily the relative differences between functionalisation rates of primary and secondary aerosol fractions, illustrating the potential of this approach in discriminating the origins of OA. Overall, our results show clearly that photochemical aging increase both $\mathrm{RCOOH}$ and $\mathrm{RCOR}^{\prime}$ contents by nearly one order of magnitude and with an almost constant $\mathrm{RCOR}^{\prime} / \mathrm{RCOOH}$ ratio of 0.3 (between 0.2 and 0.5 ; Fig. 3). Meanwhile, $\mathrm{RNO}_{2}$ content is found to be mostly related to primary emissions and to decrease with photochemical processes.

In the following, we present a comparison between the functional group compositions of different fractions. We also introduce the partial $\mathrm{O}: \mathrm{C}^{*}$ ratios calculated based only on functional groups quantified in this study (Table 2). These ratios are compared with those reported based on HR-ToF AMS measurements (termed AMS$\mathrm{O}: \mathrm{C}$ ) for bulk OA of different fractions (Aiken et al., 2007, 2008) to infer the nature and amounts of functional groups not measured here. For SOA (OOA) in Marseille and Grenoble, we also estimated the AMS-O:C ratios, following $\mathrm{Ng}$ et al. (2011) parameterisations, as 0.60 ( 0.33 for SV-OOA and 0.84 for LV-OOA) and 0.67 , respectively.
3.2.2.1. Functional group content of PfOA. Emissions from primary fossil fuel combustion are found to be the least functionalised fraction of $\mathrm{OA}$, for which $\mathrm{RF}_{\text {total }}$ is about $20 \%$, dominated by $\mathrm{RCOOH}$ ( 1 carbon out of 50 bears one of the functions quantified here). Similar low functionalisation rates were also reported based on FTIR measurements in sites dominated by fossil fuel combustion (Russell et al., 2011). Partial O:C* ratio calculated based on this functionalisation rate is 0.036 , in agreement with AMS-O:C values measured for vehicular emissions or for ambient HOA (Hydrocarbon like OA, emitted from fossil fuel combustion, Aiken et al., 2008) predominately composed of saturated and unsaturated linear, branched and cyclic hydrocarbons (e.g. alkanes, triterpene...).

3.2.2.2. Functional group content of $B B O A$. Total functionalisation rate of organic carbon from biomass smoke is estimated by the analysis as $23 \%$, dominated by $\mathrm{RCOOH}\left(\mathrm{RCOOH} \mathrm{RF}_{\mathrm{BBOA}}=15.6 \%\right.$ or $\sim 70 \%$ of the total quantified functions). Interestingly, $\mathrm{RNO}_{2}$ is observed in noteworthy quantities in biomass smoke, with a $\mathrm{RNO}_{2}$ molar ratio of $3.5 \%$. While direct $\mathrm{RNO}_{2}$ emissions from wood burning cannot be excluded, recent observations report the presence of methyl-nitrocatechol isomers in aged BBOA plumes (Iinuma et al., 2010), the aggregate of which is lower than the total $\mathrm{RNO}_{2}$ in our case, accounting for $0.2 \mathrm{RNO}_{2} \% \mathrm{BBOA}$ carbon. Iinuma et al. (2010) postulated that such compounds are of secondary origin arising from the photochemical reaction of m-cresol (Iinuma et al., 2010), contained in biomass smoke at considerable levels. They estimated that $\mathrm{m}$-cresol SOA comprises up to $11 \% \mathrm{RNO}_{2}$, based on the contribution of methyl-nitrocatechols. In our case, the multiregression analysis allocated, perhaps erroneously, $\mathrm{RNO}_{2}$ to $\mathrm{BBOA}$ rather than to SOA. This is because these compounds show some anti-correlation with SOA, as they chiefly occur simultaneously with BBOA during winter, and decrease, during summer when SOA is highest, due to their photochemical decay and the absence of BBOA VOC precursors. Therefore, the BBOA functional group composition presented in Fig. 3 and Table 2 describes that of a mix of fresh and aged biomass smoke.

BBOA Partial O:C* ratio can be estimated as 0.042 , significantly lower than values determined based on HR-ToF-AMS analysis $(0.3<0$ : $<0.4$; Aiken et al., 2008). This large difference can be ascribed to functional groups not measured here, including for the most part alcohols $(-\mathrm{OH})$ and ether groups $(-\mathrm{OR})$ present within sugar anhydrides (e.g. levoglucosan) and lignin breakdown products. Indeed, such compounds contribute, on the one hand, very significantly ( $\sim 30 \%$ of OA) to the total BBOA mass (e.g. Fine et al., 2002) and are characterized, on the other hand, by O:C ratios near unity. By comparing partial $\mathrm{O}: \mathrm{C}^{*}$ ratios determined in this study with AMS-O:C values, the upper limit contribution from alcohols/ethers can be very roughly estimated as $270 \%$ of total BBOA (i.e. 1 carbon out $\sim 4$ bears these functions). This estimated value seems to make sense, as according to biomass burning organic profiles (e.g. Fine et al., 2002), contributions from only sugar anhydrides in wood smoke range between 70 and 190 alcohol/ether groups per thousand OC, accounting for a great part (up to 70\%) of the total estimated alcohol/ether contributions.

3.2.2.3. Functional group content of SOA. SOA is found to be the most functionalised fraction in terms of $\mathrm{RCOOH}$ and $\mathrm{RCOR}^{\prime}$ groups, which is qualitatively consistent with our general knowledge of this fraction (Jimenez et al., 2009 and references therein). The total functionalisation rate of SOA is estimated by the analysis as $94 \%$ ( 1 carbon out of $\sim 11$ bears one of the functions measured here), largely dominated by $\mathrm{RCOOH}$ groups (Table 2 and Fig. 3). O:C* ratio inferred from these values is 0.17 , much lower than those measured by AMS in chamber experiments $(0.25<0: \mathrm{C}<0.5$; $\mathrm{Ng}$ et al., 2011 ; Chhabra et al., 2011) and ambient atmospheres $(0.3<0:<0.9$; 

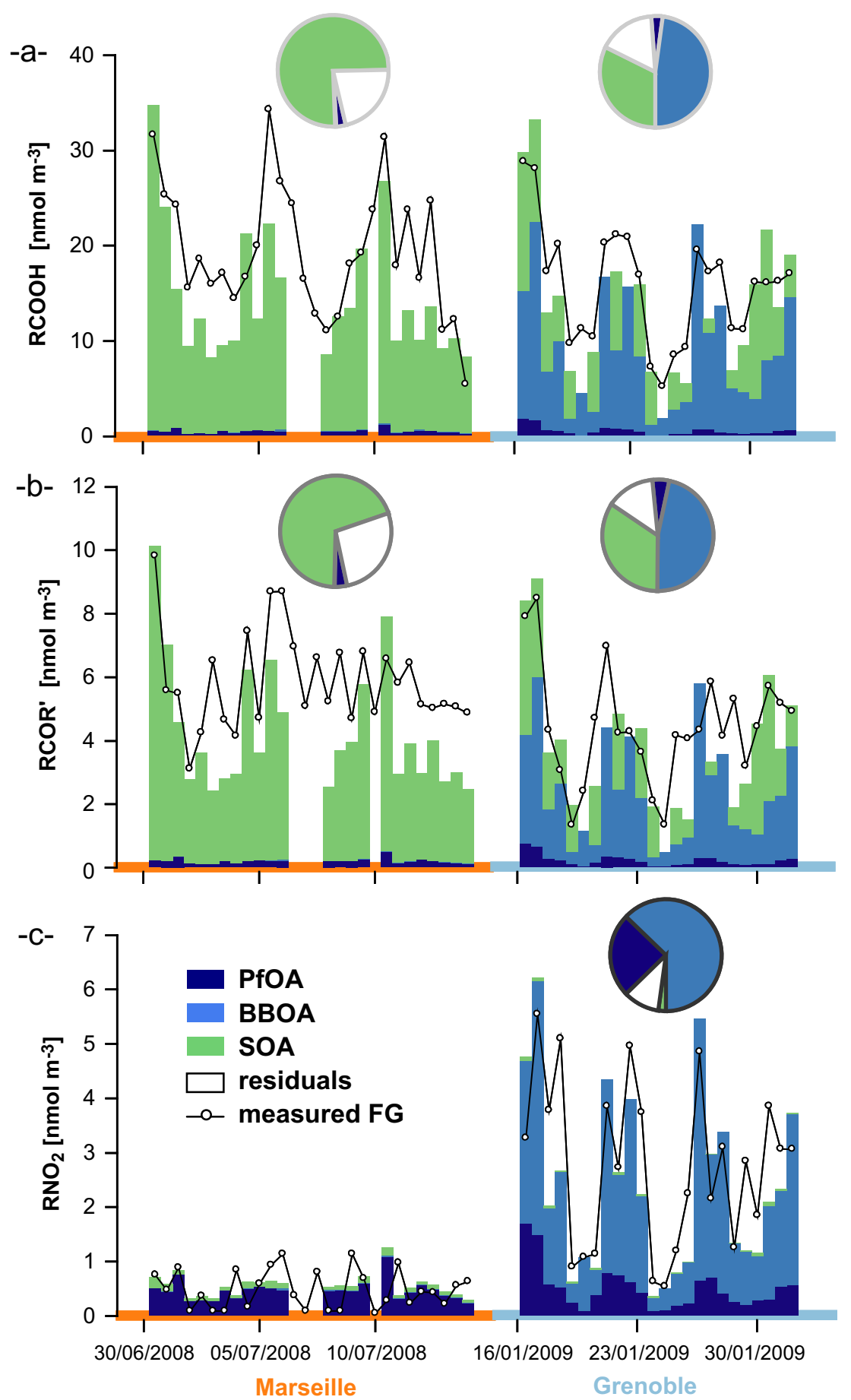

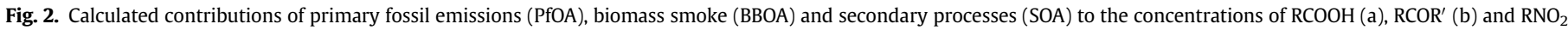

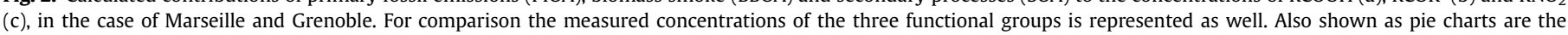

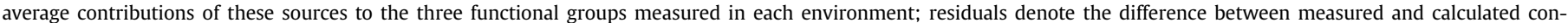
centrations. For $\mathrm{RNO}_{2}$ in the case of Marseille, average contributions are not shown as the regression overestimates the $\mathrm{RNO} 2$ concentrations $($ calculated/measured $=2.13$ ).

Jimenez et al., 2009) or estimated for OOA in Marseille $(0.60 \pm 0.21)$ and Grenoble $(0.67 \pm 0.22)$. Two assumptions can be postulated to explain these differences:

(1) as for the case of BBOA, unaccounted functions (e.g. alcohols) might explain a great part of the missing oxygen;

(2) a part of the functional groups measured here $(\mathrm{RCOOH}$ and $\mathrm{RCOR}^{\prime}$ ) is transformed in the particle phase to other forms that were not considered here, trough oligomerisation reactions (e.g. esterification; Kroll and Seinfeld, 2008 and references therein).

These assumptions are thoroughly examined in Section 3.3.

\subsection{Missing functional groups in $S O A$}

Van Krevelen diagrams can provide additional insights into the functional groups involved in the formation and evolution of SOA 

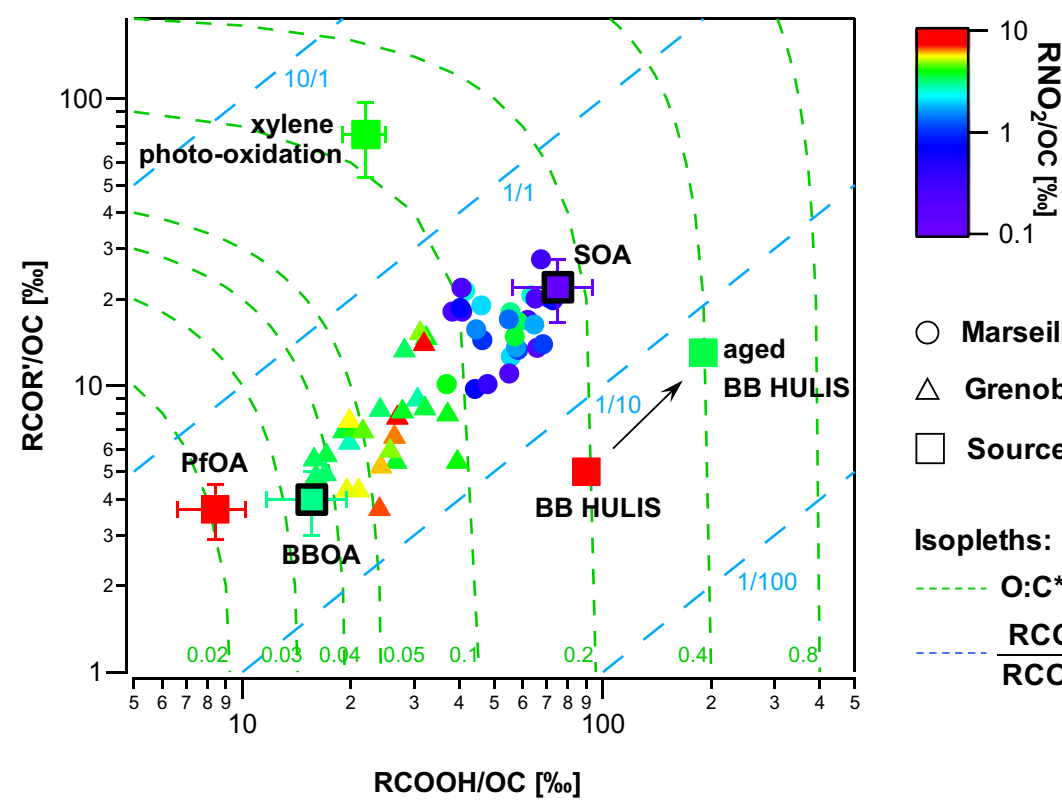

Marseille

$\triangle$ Grenoble

Sources

Isopleths:

O:C*

RCOR'

$\overline{\mathrm{RCOOH}}$

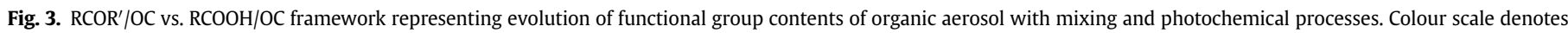

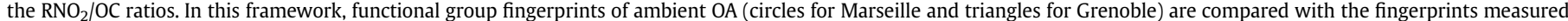

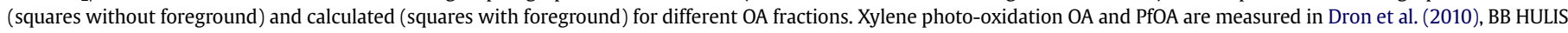

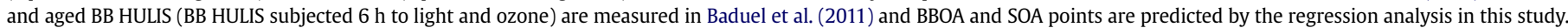

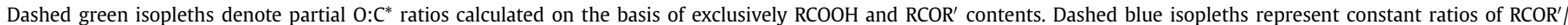
$\mathrm{RCOOH}$. (For interpretation of the references to color in this figure legend, the reader is referred to the web version of this article.)

(OOA). In this representation, the increase of $\mathrm{O}: \mathrm{C}$ ratios vs. $\mathrm{H}: \mathrm{C}$ ratios with oxidation follows specific aging lines. The slopes of these lines are dependent on the functional group added and the process by which it is added. The interpretation of such diagrams is not straightforward as many processes can be involved, some of which are illustrated in Fig. A2 - Appendix C (Evolution of functional groups in Van Krevelen diagram - Theory and examples).

Van Krevelen diagram is applied in Fig. 4 to AMS data to determine the aging line of the bulk OOA (AMS-line) in Marseille and Grenoble (data points were determined following $\mathrm{Ng}$ et al. (2011) parameterisations). Also shown is the aging line (FG-line) determined considering only the addition of the functional groups measured here ( $\mathrm{RCOR}^{\prime}$ and $\mathrm{RCOOH}$; $\mathrm{RNO}_{2}$ is discarded from this analysis as it represents very little contribution to SOA). The comparison of the slopes of both lines supports once again that functional groups other than $\mathrm{RCOR}^{\prime}$ and $\mathrm{RCOOH}$ are involved in the formation and aging of OOA: the slope of the AMS-line is -0.3 , much higher than that estimated for the FG-line (-1.22, Fig. 4). Whilst oligomerisation reactions were previously suggested as a possible reason for the low $\mathrm{RCOOH}$ content in biogenic aerosols (Russell et al., 2011), such high slope cannot be explained by oligomerisation reactions (e.g. esterification or aldolisation, Appendix C) that are associated with highly negative slopes and relatively low O:C products. Therefore, the more likely scenario (assumption 1) implies that the remaining oxygen is attributed to alcohols $(\mathrm{ROH})$, organic peroxides $(\mathrm{ROOH})$, organonitrates $\left(\mathrm{RONO}_{2}\right)$ and/or organosulfates $\left(\mathrm{ROSO}_{3} \mathrm{H}\right)$ (collectively referred to as ROX), groups that increase the $\mathrm{O}: \mathrm{C}$ ratio of $\mathrm{OOA}$ without decreasing its $\mathrm{H}: \mathrm{C}$ ratio (slope $=0$, Figs. 4 and A2; although other processes cannot be ruled out, e.g. fragmentation, Appendix C).

Considering the latter scenario, the comparison between the partial $0: C^{*}$ ratio $(0.17)$ and the average AMS-O:C ratio estimated for OOA (0.63) enables to estimate the functionalisation rates of $\mathrm{ROH}, \mathrm{ROOH}, \mathrm{RONO}_{2}$ or $\mathrm{ROSO}_{3} \mathrm{H}$ as $460 \pm 240 \%, 230 \pm 120 \%$, $173 \pm 80 \%$ and $115 \pm 60 \%$, respectively (most of the uncertainties related to these estimates stems from O:C ratio errors, estimated as

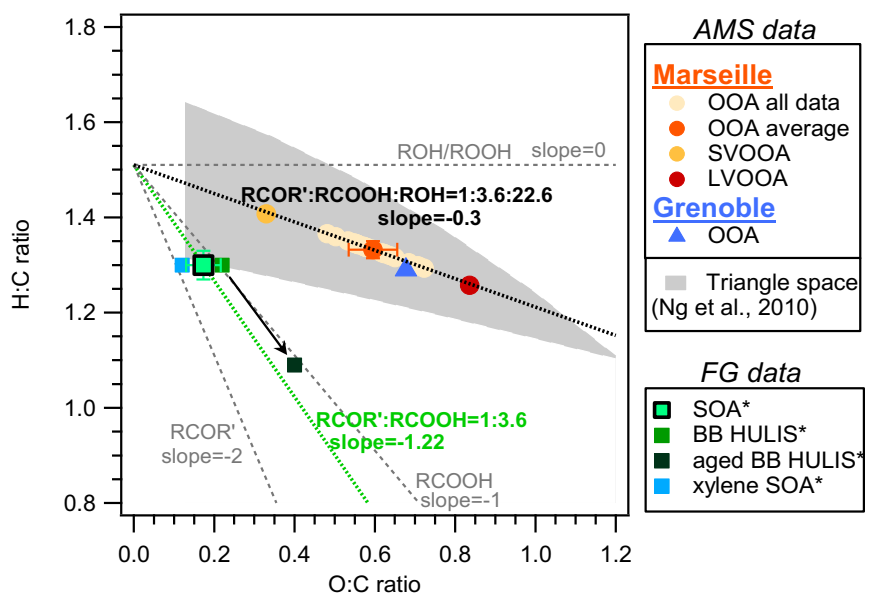

Fig. 4. Van Krevelen diagram illustrating how functionalisation reactions of organic species affect $\mathrm{H}: \mathrm{C}$ and $\mathrm{O}: \mathrm{C}$ ratios of the organic matter. Each gray dashed line having different slopes illustrates the addition of a particular functional group ( $\mathrm{RCOR}^{\prime}, \mathrm{RCOOH}$ and $\mathrm{ROH}$ ) to an aliphatic un-functionalised carbon. The starting point of these lines (i.e. $\mathrm{O}: \mathrm{C}=0$ and $\mathrm{H}: \mathrm{C}=1.51$, un-functionalised carbon having an average molecular formula of $\left.\left[\mathrm{C}_{4} \mathrm{H}_{6}\right]_{n}\right)$ is obtained by fitting the $\mathrm{H}: \mathrm{C}$ and $\mathrm{O}: \mathrm{C}$ ratios of oxygenated organic aerosol (OOA) resulting from PMF analysis of Marseille and Grenoble AMS data (AMS-line). OOA H:C and O:C ratios are calculated based on $\mathrm{m} / \mathrm{z} 43$ and $\mathrm{m} / \mathrm{z} 44$ signal fractions, respectively, using the $\mathrm{Ng}$ et al. (2011) parameterisation. VK-triangle parameterization developed in the latter paper, enclosing OOA fractions observed in the ambient, is represented by the gray area. In parallel, also represented are SOA partial $\mathrm{H}: \mathrm{C}^{*}$ and $\mathrm{O}: \mathrm{C}^{*}$ ratios calculated based on $\mathrm{RCOOH}$ and $\mathrm{RCOR}^{\prime}$ functional groups measured here (FGline). The $\mathrm{H}: \mathrm{C}^{*}$ ratio value is estimated based on the $\mathrm{O}: \mathrm{C}^{*}$ ratio of SOA $(0.17$, Table 2$)$ and the $\mathrm{RCOR}^{\prime}: \mathrm{RCOOH}$ ratio of $1: 3.6$ measured for SOA represented by the dashed green line $\left(\mathrm{H}: \mathrm{C}^{*}=-1.22 \times 0: \mathrm{C}^{*}+1.51\right)$. Likewise, $\mathrm{H}: \mathrm{C}^{*}$ and $\mathrm{O}: \mathrm{C}^{*}$ ratios of BB HULIS, aged BB HULIS and xylene photo-oxidation SOA are calculated and shown in the figure. The comparison between the partial $\mathrm{O}: \mathrm{C}^{*}$ ratio of SOA and the average $\mathrm{O}: \mathrm{C}$ ratio estimated for OOA (0.63) enables to estimate the ROH content at $460 \% \mathrm{OC}$ (or ROOH/ OC of $230 \%$ or RSO $4 \mathrm{H} / \mathrm{OC}$ of $115 \%$ ) or a $\mathrm{RCOR}^{\prime}: \mathrm{RCOOH}: \mathrm{ROH}$ ratio of $1: 3.6: 22.6$. Based on this prediction, aging slope is estimated at -0.3 and represented by the dashed black line $\left(\mathrm{H}: \mathrm{C}^{*}=-0.3 \times 0: \mathrm{C}^{*}+1.51\right)$ which seems to characterise very well the $\mathrm{H}: \mathrm{C}$ and $\mathrm{O}: \mathrm{C}$ ratios of OOA. (For interpretation of the references to color in this figure legend, the reader is referred to the web version of this article.) 
$30 \%$ by Aiken et al., 2007). Based on these predictions and the measured $\mathrm{RCOR}^{\prime}$ and $\mathrm{RCOOH}$, one can reconstruct a predicted aging line for OOA (e.g. considering the following functional group proportions RCOR':RCOOH:ROH of 1:3.6:22.6, dashed black line, Fig. 4). The slope of this line strongly matches that of the AMS-line representative of the bulk OOA ( -0.3$)$, supporting the considered scenario and the high proportions of ROX groups. Numerous observations and model predictions tend to confirm such high proportions. FTIR measurements of functional groups in ambient OA suggest that ROH can contribute up to $400 \%$ o (Russell et al., 2011), especially in marine biogenic environments, like Marseille. These results are also supported by explicit models of SOA formation (up to $300 \%$ of ROH, Camredon et al., 2007; Valorso et al., 2011) and by the detection of polyols in many SOA systems (e.g. isoprene and naphthalene SOA, Surratt et al., 2006; Kautzman et al., 2010). Furthermore, in Marseille, with the predominance of regional transport (El Haddad et al., 2012), a part of SOA is expected to be formed under low $\mathrm{NO}_{\mathrm{x}}$ conditions, which enhance $\mathrm{ROH}$ and $\mathrm{ROOH}$ production (e.g. Kroll and Seinfeld, 2008; Valorso et al., 2011 and reference therein). Nevertheless, similar to $\mathrm{RNO}_{2}, \mathrm{ROOH}$ groups are prone to photochemistry and can decay under summertime conditions, hindering their build up in SOA. In this regard, recent chamber experiments seem to suggest that under such conditions ROOH reaches a steady state below $20 \%$ (upper limit contribution of $50 \%$ in fresh SOA), depending on the $\mathrm{NO}_{\mathrm{x}}$ concentrations (Mertes et al., 2012). Always in the case of Marseille, $\mathrm{ROSO}_{3} \mathrm{H}$ were shown to potentially constitute a substantial fraction of SOA (El Haddad et al., 2011b). Conversely, in the case of Grenoble (Favez et al., 2010), $\mathrm{RONO}_{2}$ is expected to play a major role as most of the aging takes place under high $\mathrm{NO}_{\mathrm{x}}$ conditions (Valorso et al., 2011 and reference therein). Nevertheless, it should be noted that a significant part of $\mathrm{ROSO}_{3} \mathrm{H}$ and $\mathrm{RONO}_{2}$ are detected in the AMS as inorganic sulfate and nitrate, respectively (Farmer et al., 2010) and might not explain the higher $\mathrm{O}: \mathrm{C}$ ratios determined by AMS. In light of these results, quantification of ROX functional groups is of utmost importance, allowing establishing an oxygen mass balance in OA and in turn better characterising the processes by which SOA is formed and evolves in the atmosphere and confirming the outputs of explicit models (Valorso et al., 2011).

\section{Acknowledgement}

This work was funded by «Le Ministère de l'Ecologie, du Développement et de l'Aménagement Durable» and by «l'Agence gouvernementale De l'Environnement et de la Maîtrise de l'Energie (ADEME)», under the PRIMEQUAL2 grant $n^{\circ} 0001135$ (FORMES project). Imad El Haddad is grateful to the Swiss national science foundation (SNSF) for the postdoctoral fellowship SNSF_SAPMAV_200021_130169.

\section{Appendix A. Functional group analyses}

Functional group analysis is carried out, following a recently developed analytical approach based on atmospheric pressure chemical ionization-tandem mass spectrometry analysis (APCI-MS/ MS). The approach enables quantitative determination of carboxylic $(\mathrm{RCOOH})$, carbonyls $\left(\mathrm{RCOR}^{\prime}\right)$, and nitro $\left(\mathrm{RNO}_{2}\right)$ functional groups. It is based on the ability of functional groups to lose a specific neutral molecular fragment (neutral loss scanning, NL) or to produce a characteristic fragment ion (precursor ion scanning, PAR) upon fragmentation in the collision cell. Details regarding the analytical procedure are fully presented in Dron et al. (2007, 2008a,b, 2010) and the main analytical characteristics are reported in Table A1.
First, samples are solvent extracted with a methanol/hexane mix (2/1 v:v) at $100{ }^{\circ} \mathrm{C}$ and 100 bars using an accelerated pressurized solvent extraction device (ASE 300, Dionex). The extracts are subsequently concentrated down to $0.5 \mathrm{ml}$, by the mean of an automatic concentrator (TurboVap II) and finally diluted in methanol to a volume of $3.5 \mathrm{ml}$. This final volume is divided into several fractions to determine the concentrations of the different functional groups. The APCI-MS/MS analysis is performed on a Varian 1200L triple quadrupole mass spectrometer equipped with an APCI ionisation chamber, a Varian Prostar 410 auto-sampler and a Varian 210 high-performance liquid chromatography (HPLC) system. Solutions were directly injected into the APCI at a flow rate of $0.5 \mathrm{ml} \mathrm{min}^{-1}$, using the HPLC pump and total ion current (TIC) mass spectra were recorded (between $\mathrm{m} / \mathrm{z} 100$ and $\mathrm{m} / z 800$ for $\mathrm{RCOOH}$ and $\mathrm{RNO}_{2}$ and between $\mathrm{m} / z 200$ and $\mathrm{m} / \mathrm{z} 800$ for $\mathrm{RCOR}^{\prime}$ ).

For the analysis of carboxylic functional groups, a $300 \mu \mathrm{L}$ fraction of the extracts is first submitted to derivatisation, in order to convert the carboxylic groups into their corresponding methyl esters. This was achieved by adding $300 \mu \mathrm{L}$ of a boron trifluoride methanolic solution (BF3/methanol 14\% v/v) and heating for $2 \mathrm{~h}$ at $70{ }^{\circ} \mathrm{C}$. The APCI-MS/MS analysis is performed by scanning in the positive mode the neutral loss of methanol $\left(\mathrm{CH}_{3} \mathrm{OH}, 32 \mathrm{amu}\right.$ : NL32) resulting from the fragmentation of the protonated methyl esters. Non-derivatized aliquots are also analysed following the same procedure in order to subtract the residual NL32 signal associated with interference from non carboxylic moieties (Dron et al., 2007).

For the quantification of carbonyls, i.e. aldehyde and ketone groups, a second fraction of $450 \mu \mathrm{L}$ of the initial extract is derivatized for $18 \mathrm{~h}$ at room temperature with $150 \mu \mathrm{L}$ of pentafluorophenylhydrazine (PFPH) at $100 \mathrm{mM}$ in methanol. The derivatized carbonyls (pentafluorophenyl hydrazones) are then monitored in the positive mode, by detecting the neutral loss of $\mathrm{C}_{6} \mathrm{~F}_{5} \mathrm{~N}$ fragment (181 amu: NL181). Another aliquot of $450 \mu \mathrm{L}$ is mixed with $150 \mu \mathrm{L}$ of methanol and analysed in the same mode for the measurement of NL181 background of the underivatized extract (Dron et al., 2008a).

The last fraction is directly analysed in the negative mode of the APCI using the precursor ion scanning of the nitrite fragment ion $\left(\mathrm{NO}_{2}^{-}, m / z\right.$ 46: PAR46) to determine nitro functional groups (Dron et al., 2008b).

Table A1

Analytical method characteristics.

\begin{tabular}{llll}
\hline & $\mathrm{RCOOH}$ & $\mathrm{RCOR}^{\prime}$ & $\mathrm{RNO}_{2}$ \\
\hline Concentration range $[\mathrm{mM}]$ & $0.01-0.5$ & $0.005-0.25$ & $0.002-0.1$ \\
Detection limits [mM] & 0.005 & 0.004 & 0.001 \\
Estimated uncertainties $^{\mathrm{a}}$ & $12 \%$ & $19 \%$ & $15 \%$ \\
Extraction efficiency $^{\prime}$ & $83 \%$ & $66 \%$ & $70 \%$
\end{tabular}

${ }^{a}$ Uncertainties are estimated in Dron et al. (2007, 2008a,b).

As the fragmentation is affected by the compounds molecular structures, the calibration is based on reference mixtures containing high number of compounds having various chemical structures and including mono and poly functional molecules (16, 24 and 31 standard compounds for nitro, carbonyl and carboxylic groups, respectively). For each functional group, 25 reference mixtures of equal total concentrations in terms of functional groups are analysed. For each of these mixtures, the individual compound concentrations were randomly determined. The relative standard deviations (RSD) of the responses of the different calibration mixtures are in the range $10-20 \%$ (Table A1). This particular calibration procedure involving a statistical analysis of reference mixtures attested its reliability when applied to complex mixtures (Dron et al., 2007, 2008a,b, 2010). Calibration 

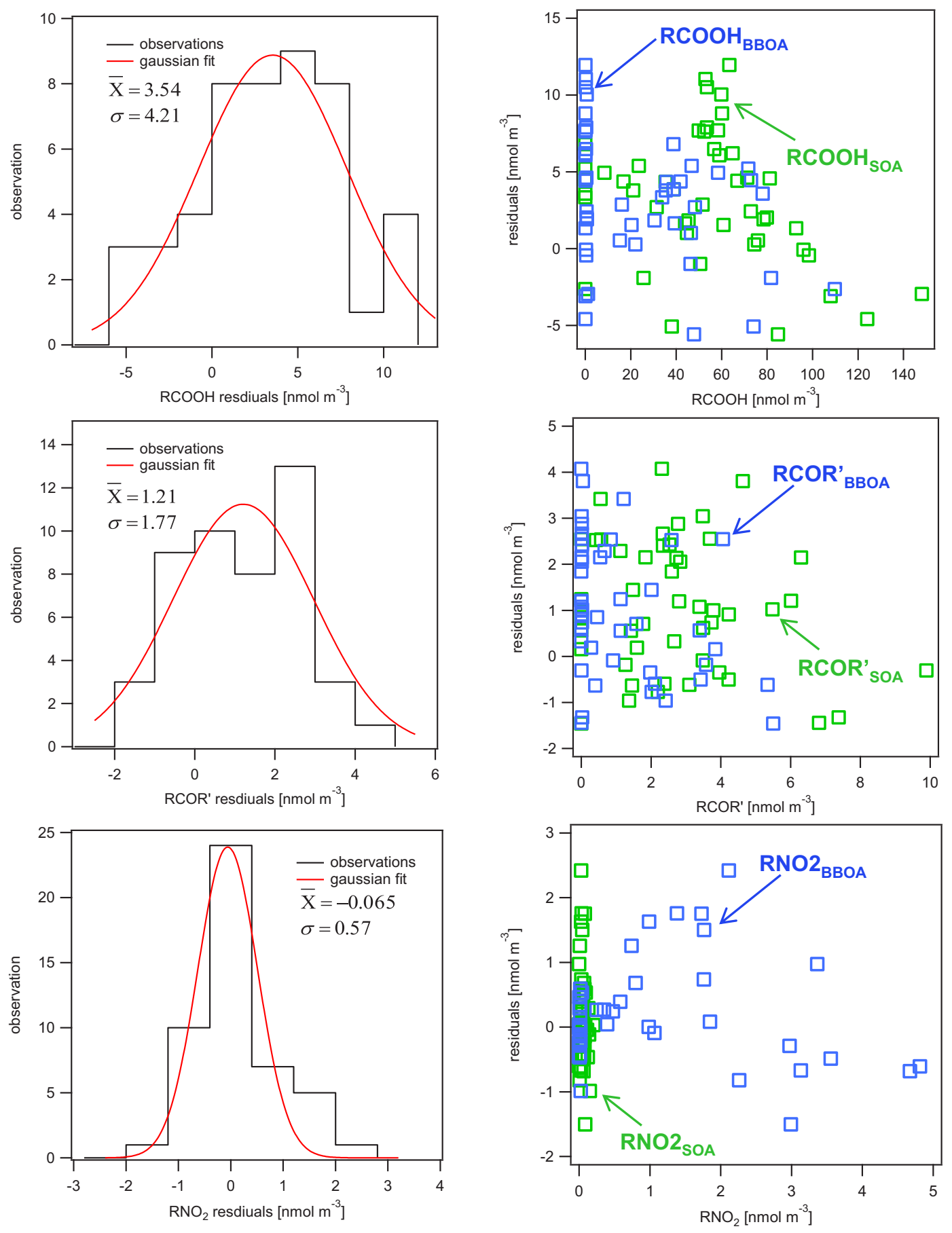

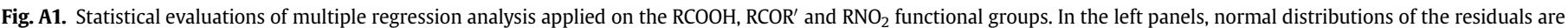

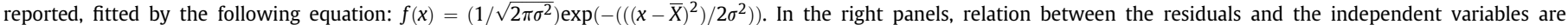
examined.

samples are analysed within each sequence. Field blank filters were also analysed following the same procedure and the results were all below detection limits $(0.005 \mathrm{mM}, 0.004 \mathrm{mM}$, and $0.001 \mathrm{mM}$ for $\mathrm{RCOOH}, \mathrm{RCOR}^{\prime}$, and $\mathrm{RNO}_{2}$, respectively, Table A1). The extraction efficiency of functional groups is assessed by extracting filters spiked with functional groups standard solutions with known concentrations. The extraction efficiency of RCOOH, RCOR' and $\mathrm{RNO}_{2}$ are 83, 66 and $70 \%$, respectively (Table A1). Data are all corrected for losses during extraction and sample concentration.
It should be also noted that high volume sampling is associated with considerable adsorption and volatilisation artefacts. The net artefact for $\mathrm{OC}$ is positive in our case, estimated for Marseille and Grenoble, as $28 \%$ and $9 \%$ respectively based on comparisons between OC results from filters sampled by low pressure impactor and high volume sampler. Functional group and OC data reported here are not corrected for sampling artefacts. Assuming that these artefacts equally affect functional groups (FG) and OC, they will indeed bias high absolute FG concentrations but would cancel out when FG are normalized to $\mathrm{OC}$ to retrieve functionalisation rates (RF). 


\section{Appendix B. Multiple regression analysis - principles, evaluation and limitations}

In order to quantitatively determine functionalisation rates of organic aerosols emitted or formed via different sources, a multiple regression analysis is used. It combines measured concentrations of functional groups (dependant variables) and relative contributions of the impacting sources to organic aerosol (independent variables).

In the equations, the concentration of a considered functional group measured at the receptor site ( $\left.\mathrm{FG}_{\text {measured }}\right)$ can be expressed as the sum of the concentrations of this functional group derived from the different sources. This is described in Eq. (1) for a total number of sources $n$, where $F_{i}$ is the concentration of the considered functional group emitted from source $i$. The term $\xi$ denotes the residual functional group concentration that cannot be assigned to any of the considered sources. Eq. (1) can be expressed as a function of the functionalisation rates of $\mathrm{OC}[\%]$ emitted from the considered sources $\left(\mathrm{RF}_{i}\right)$ and the concentrations $\left[\mu \mathrm{mol} \mathrm{m}{ }^{-3}\right]$ of OC derived from these sources $\left(\mathrm{OC}_{i}\right)$, as presented in Eq. (2). That is, the parameters $\mathrm{RF}_{i}$ can be inferred from the $\mathrm{FG}_{\text {measured }}$ and the $\mathrm{OC}_{i}$ matrices included as inputs in the equations.

$\mathrm{FG}_{\text {measured }}=\mathrm{FG}_{1}+\mathrm{FG}_{2}+\cdots+\mathrm{FG}_{n}+\xi=\sum_{i}^{n} \mathrm{FG}_{i}+\xi$

$$
\begin{aligned}
\mathrm{FG}_{\text {measured }} & =\mathrm{RF}_{1} \times \mathrm{OC}_{1}+\mathrm{RF}_{2} \times \mathrm{OC}_{2}+\cdots+\mathrm{RF}_{n} \times \mathrm{OC}_{n}+\xi \\
& =\sum_{i}^{n} \mathrm{RF}_{i} \times \mathrm{OC}_{i}+\xi
\end{aligned}
$$

In practice, for each functional group, Eq. (2) is resolved using a weighted least square solution, where the two datasets of Grenoble and Marseille are included simultaneously. In our case, the organic aerosol source contributions ( $\mathrm{OCi}$, in $\mu \mathrm{mol} \mathrm{m}{ }^{-3}$ ) were apportioned using a CMB model that takes into consideration the three most predominant sources, including fossil fuel combustion-PfOA, biomass burning-BBOA and secondary sources-SOA (see El Haddad et al., 2011a for the case of Marseille and Favez et al., 2010 for the case of Grenoble). For PfOA, the functionalisation rates $\mathrm{RF}_{i}$ determined empirically by tunnel measurements (El Haddad et al., 2009; Dron et al., 2010) were integrated in the multiple regression analysis, because the models were not able to provide statistically significant results for these parameters (for $\mathrm{RCOOH} / \mathrm{OC}_{\mathrm{PfOA}} p=0.18$ and for $\mathrm{RNO}_{2}$ / ${ }_{\text {OC }}$ PfOA $p=0.32$ ).

Table A2 presents the functionalisation rates $\left(R_{i}\right)$ of the different fractions estimated by the multiple regression analysis and the associated uncertainties, ranging between 5\% and 75\% (average $20 \%$ ) depending on $\mathrm{RF}_{i}$. For all functional groups, the independent variables are not linearly related and the parameters $\mathrm{RF}_{i}$ associated with BBOA and SOA are all statistically significant. The constant parameters $\xi$ for all functional groups are not statistically different than zero. Assumptions underlying the residuals distributions are examined in Fig. A1. Residuals follow normal distributions with mean values statistically equal to zero, implying that errors are homoscedastic (variance $=0$ ) and are not correlated. Right panels in Fig. A1 show that for all functional groups the residuals do not show any correlation with the independent variables.

\section{Table A2}

Organic carbon functionalisation rates of fossil fuel combustion emissions (PfOA) biomass burning (BBOA) and SOA estimated by the multiple regression analysis for the three functional groups measured in this study. The uncertainties denote error estimates by the analysis.

\begin{tabular}{llrr}
\hline $\mathrm{RF}[\%]$ & PfOA & \multicolumn{1}{c}{ BBOA } & \multicolumn{1}{c}{ SOA } \\
\hline $\mathrm{RCOOH}$ & $8.4 \pm 1.5$ & $15.6 \pm 1.4$ & $74.0 \pm 4.2$ \\
$\mathrm{RCOR}^{\prime}$ & $3.4 \pm 0.8$ & $4.0 \pm 0.5$ & $20.5 \pm 1.4$ \\
$\mathrm{RNO}_{2}$ & $8.1 \pm 2.2$ & $3.5 \pm 0.3$ & $0.4 \pm 0.3$ \\
\hline
\end{tabular}

Despite the robustness of the regression analysis outputs, in some cases, the calculation fails to achieve closer and higher residuals are consequently obtained (notably in Marseille's case), implying some remaining variability. Indeed, such discrepancies between measured and calculated concentrations can be partially assigned to uncertainties associated with FG measurements and/ or CMB estimates and to unconsidered minor contributing sources. However, the major limitation of the analysis used here stems, in our opinion, from the fact that it does not account for potential variability in the functional group fingerprint of $\mathrm{OA}$ derived from the same process. With regards to primary emissions, it was shown, in particular for biomass smoke, that important variability of the functional group fingerprint can be observed according to combustion conditions (Dron et al., 2010). This variability might be even higher for the secondary fraction whose oxidation state strongly depends on the precursors' chemical nature (Chhabra et al., 2011), as in Marseille SOA precursors are dominated by biogenic volatile organic compounds (El Haddad et al., 2011b), whilst in Grenoble, SOA is more likely to be generated through aging of primary emissions (Favez et al., 2010). Additionally, both primary and secondary fractions can undergo further photochemical processing during atmospheric transport (Donahue et al., 2009) and variability in photochemical age of air masses introduce most likely variability in the functional group content of the collected aerosol. Accordingly, $\mathrm{RF}_{i}$ parameters determined here must be regarded as average estimates of functionalisation rates of $\mathrm{OA}$ derived from direct emissions (PfOA and BBOA fractions) and photochemical processes (SOA fraction).

\section{Appendix C. Evolution of functional groups in Van Krevelen diagram - theory and examples}

Recently, Van Krevelen diagrams representing $\mathrm{H}: \mathrm{C}$ vs. O:C ratios were frequently utilized to investigate the processes involved in atmospheric aging of particulate organic matter, as these representations may help highlighting the type of functional groups formed (Heald et al., 2010; Chhabra et al., 2011; $\mathrm{Ng}$ et al., 2011). However, the representation of functional group formation in Van Krevelen diagram is not always straightforward and Fig. A2 illustrates this complexity showing different possible scenarios representative of atmospheric reactions taken from state of the art literature (Kroll and Seinfeld, 2008; Hallquist et al., 2009). In these representations, $\mathrm{O}: \mathrm{C}$ ratios always increase proportionally with the increase of functional group rates (see Fig. A2a, b and c) and one can straightforwardly estimate these ratios by knowing the type and the amount of functional groups added. Conversely, $\mathrm{H}: \mathrm{C}$ ratios cannot be estimated in the same manner as they depend on the unsaturation rate of the un-functionalised matter and the process by which the functional group is added to this matter. The unsaturation rate of the un-functionalised matter was here represented by an aging starting point considered as the $\mathrm{H}: \mathrm{C}$ value at $\mathrm{O}:=0$ and estimated as 1.51 by fitting the AMS data. This absolute $\mathrm{H}: \mathrm{C}$ value has to be regarded with caution as it may not 
a) FG addition on un-functionalized OC

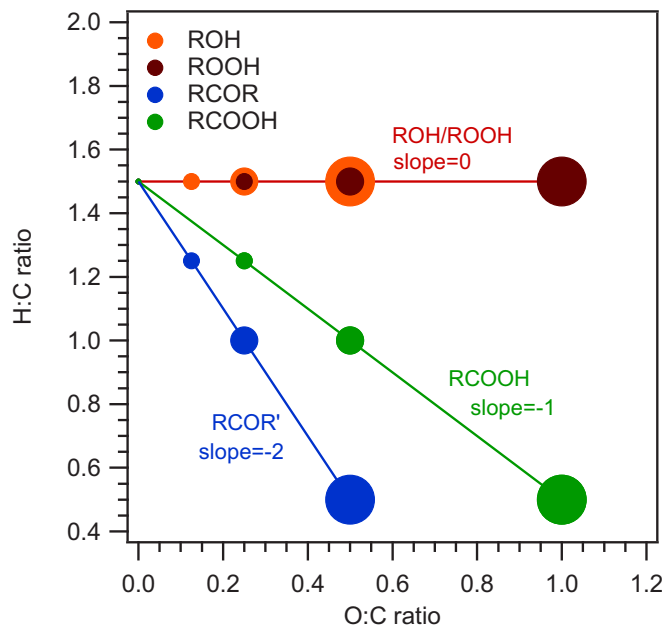

c) FG oxidation

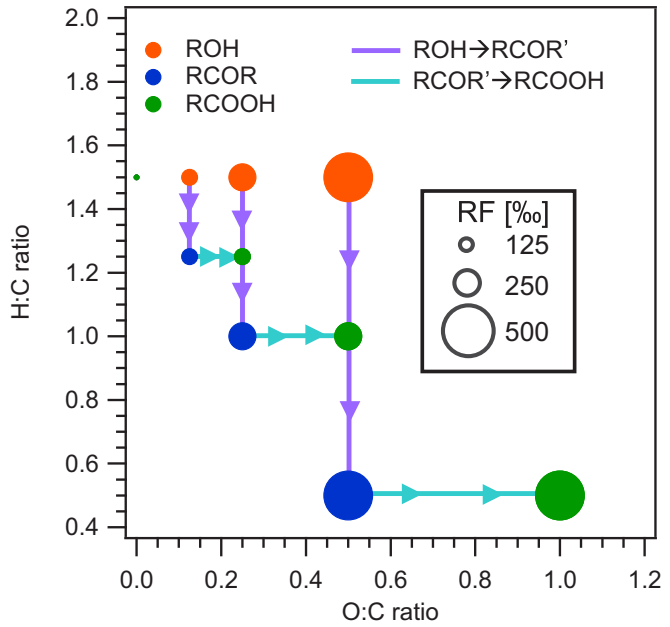

b) double bonds evolution (breakdown* or addition**)

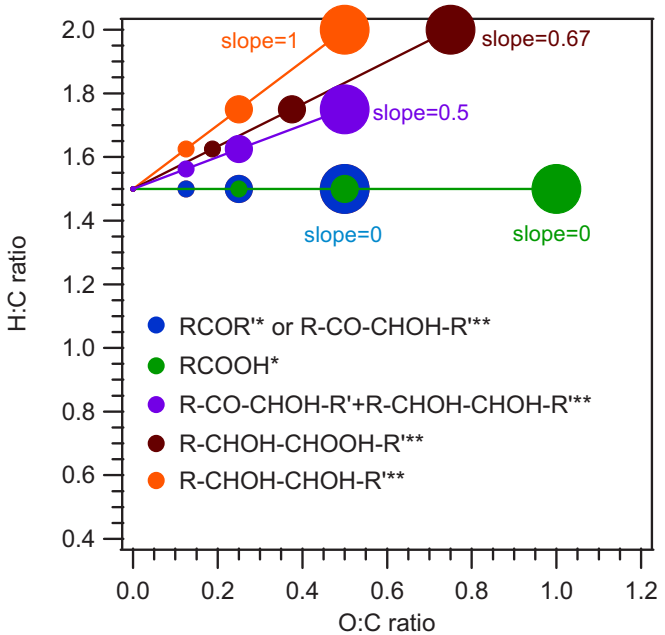

d) oligomerisation (e.g. esterification)

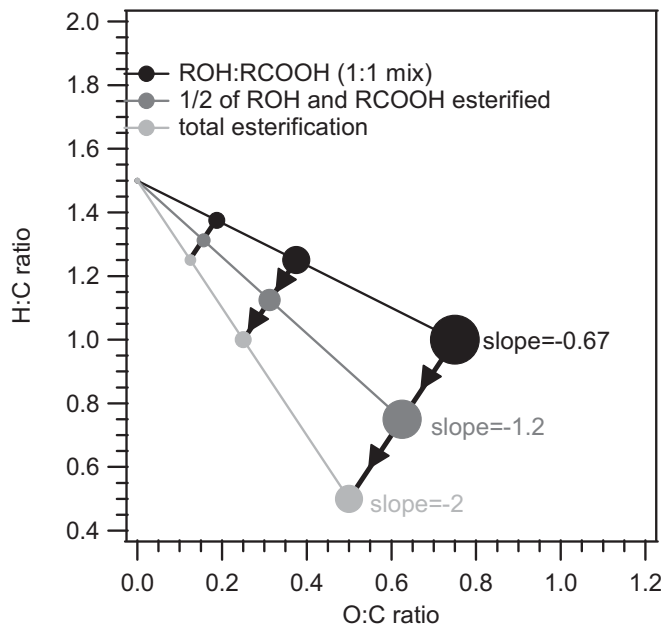

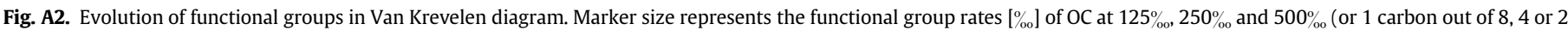

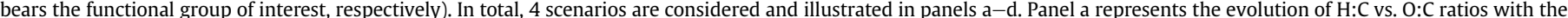

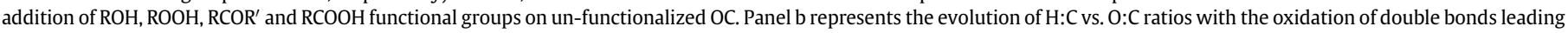

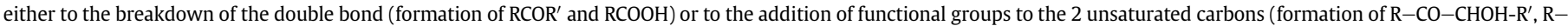

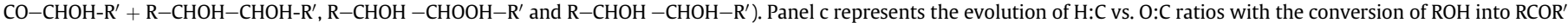

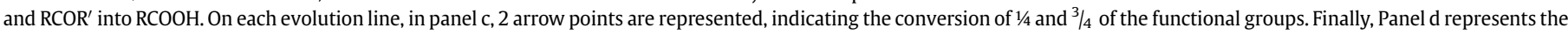
evolution of $\mathrm{H}: \mathrm{C}$ vs. O:C ratios with the esterification of a $\mathrm{ROH}: \mathrm{RCOOH}$ 1:1 mix. This type of molecular reaction lead to a decrease of RF, $\mathrm{H}: \mathrm{C}$ ratios and $\mathrm{O}: \mathrm{C}$ ratios.

reflect the actual starting point and only relative changes in this ratio can be considered relevant. These changes can be examined by the slopes of the aging lines and are dependent on the process by which the functional group is added. Steep negative slopes indicate a large loss of hydrogen atoms with the addition/formation of functional groups. Examples illustrating these processes include addition of carbonyls and carboxylic groups on saturated carbon (Fig. A2a) and the conversion of an alcohol group into a carbonyl group (Fig. A2.c). In contrast, slopes equal to zero or positive slopes represent processes by which the addition of the functional group does not change or increase the amount of hydrogen atoms in the matter, respectively. These processes comprise the addition of $\mathrm{ROH}$ or $\mathrm{ROOH}$ on saturated carbon, the formation of $\mathrm{RCOR}^{\prime}$ or $\mathrm{RCOOH}$ upon the breakdown of double bonds (e.g. ozonolysis), the formation of dihydroxy (e.g. methyltetrols), hydroxyl-hydroperoxides and hydroxyl-carbonyls upon the addition of $\mathrm{OH}$ radical on the double bond and the conversion of a $\mathrm{RCOR}^{\prime}$ group into a $\mathrm{RCOOH}$ group. It should be noted that owing to the high reactivity of double bonds, processes involving their oxidation (fragmentation/addition) are expected to prevail only during the first oxidation steps (i.e. oxidation of unfuntionalized olefins/terpenes such as $\alpha$-pinene) and have less impact on the aging of secondary particle phase material (e.g. transformation of SVOOA into LVOOA). At this step, other fragmentation pathways involving the cleavage of $\mathrm{C}-\mathrm{C}$ simple bonds of oxygenated compounds are likely to prevail, increasing the $\mathrm{O}: \mathrm{C}$ ratios due to a loss of carbon. However, the products resulting from such mechanisms are expected to be more volatile than their oxygenated precursors and thus it is unlikely that they significantly contribute to LVOOA (Kroll et al., 2009).

Unlike the aforementioned processes, molecular oligomerisation mechanisms such as esterification, acetal formation or aldol condensation reduce both $\mathrm{H}: \mathrm{C}$ and $\mathrm{O}: \mathrm{C}$ ratios and lead to a decrease in the overall functional group balance. Fig. A2d illustrates the evolution of $\mathrm{H}: \mathrm{C}$ vs. O:C ratios with the esterification of a ROH:R$\mathrm{COOH} 1: 1 \mathrm{mix}$. In the example, the esterification of the total $\mathrm{ROH}$ and $\mathrm{RCOOH}$ groups leads to a decrease of the functionalisation rate and the $\mathrm{O}: \mathrm{C}$ ratios by a factor of 2 and 1.5 , respectively. 
Indeed, processes represented here cannot be considered as exhaustive and several others can be involved in the formation and evolution of secondary organic aerosol. In the ambient atmosphere, a mix between these processes most probably takes place. This can be translated in Van Krevelen diagrams by an average aging line weighted by the importance of each process involved.

\section{References}

Aiken, A.C., DeCarlo, P.F., Jimenez, J.L., 2007. Elemental analysis of organic species with electron ionization high-resolution mass spectrometry. Analytical Chemistry 79, 8350-8358. http://dx.doi.org/10.1021/ac071150w.

Aiken, A.C., Decarlo, P.F., Kroll, J.H., Worsnop, D.R., Huffman, J.A., Docherty, K.S., Ulbrich, I.M., Mohr, C., Kimmel, J.R., Sueper, D., Sun, Y., Zhang, Q., Trimborn, A., Northway, M., Ziemann, P.J., Canagaratna, M.R., Onasch, T.B., Alfarra, M.R., Prevot, A.S.H., Dommen, J., Duplissy, J., Metzger, A., Baltensperger, U. Jimenez, J.L., 2008. O/C and OM/OC ratios of primary, secondary, and ambient organic aerosols with high-resolution time-of-flight aerosol mass spectrometry Environmental Science and Technology 12, 4478-4485. http://dx.doi.org/ 10.1021/es703009q

Baduel, C., Monge, M.E., Voisin, D., Jaffrezo, J.L., George, C., El Haddad, I., Marchand, N., D'Anna, B., 2011. Oxidation of atmospheric humic like substances by ozone: a kinetic and structural analysis approach. Environmental Science and Technology 45 (12), 5238-5244. http://dx.doi.org/10.1021/es200587z.

Camredon, M., Aumont, B., Lee-Taylor, J., Madronich, S., 2007. The SOA/VOC/NOx system: an explicit model of secondary organic aerosol formation. Atmospheric Chemistry and Physics, 5599-5610. http://dx.doi.org/10.5194/acp-7-55992007.

Cavalli, F., Viana, M., Yttri, K.E., Genberg, J., Putaud, J.-P., 2010. Toward a standardised thermal-optical protocol for measuring atmospheric organic and elemental carbon: the EUSAAR protocol. Atmospheric Measurement Techniques 3, 79-89. http://dx.doi.org/10.5194/amt-3-79-2010.

Chhabra, P.S., Ng, N.L., Canagaratna, M.R., Corrigan, A.L., Russell, L.M., Worsnop, D.R., Flagan, R.C., Seinfeld, J.H., 2011. Elemental composition and oxidation of chamber organic aerosol. Atmospheric Chemistry and Physics 11, 8827-8845. http://dx.doi.org/10.5194/acp-11-8827-2011.

Decesari, S., Mircea, M., Cavalli, F., Fuzzi, S., Moretti, F., Tagliavini, E., Facchini, M.C., 2007. Source attribution of watersoluble organic aerosol by nuclear magnetic resonance spectroscopy. Environmental Science and Technology 41, 24792484. http://dx.doi.org/10.1021/es0617111.

Donahue, N.M., Robinson, A.L., Pandis, S.N., 2009. Atmospheric organic particulate matter: from smoke to secondary organic aerosol. Atmospheric Environment 43, 94-106.

Drewnick, F., Hings, S.S., DeCarlo, P., Jayne, J.T., Gonin, M., Fuhrer, K., Weimer, S. Jimenez, J.L., Demerjian, K.L., Borrmann, S., Worsnop, D.R., 2005. A new time-offlight aerosol mass spectrometer (TOF-AMS) - instrument description and first field deployment. Aerosol Science and Technology 39, 637-658.

Dron, J., Eyglunent, G., Temime-Roussel, B., Marchand, N., Wortham, H., 2007. Carboxylic acid functional group analysis using constant neutral loss scanningmass spectrometry. Analytica Chimica Acta 605, 61-69.

Dron, J., Zheng, W., Marchand, N., Wortham, H., 2008a. New method to determine the total carbonyl functional group content in extractable particulate organic matter by tandem mass spectrometry. Journal of Mass Spectrometer 43 , 1089-1098.

Dron, J., Abidi, E., El Haddad, I., Marchand, N., Wortham, H., 2008b. Precursor ion scanning-mass spectrometry for the determination of the nitro functional groups in atmospheric particulate organic matter. Analytica Chimica Acta 618 184-195.

Dron, J., El Haddad, I., Temime-Roussel, B., Jaffrezo, J.-L., Wortham, H., Marchand, N. 2010. Functional group composition of ambient and source organic aerosols determined by tandem mass spectrometry. Atmospheric Chemistry and Physics 10, 7041-7055. http://dx.doi.org/10.5194/acp-10-7041-2010.

El Haddad, I., Marchand, N., Dron, J., Temime-Roussel, B., Quivet, E., Wortham, H., Jaffrezo, J.-L., Baduel, C., Voisin, D., Besombes, J.-L., Gille, G., 2009. Comprehensive primary particulate organic characterization of vehicular exhaust emissions in France. Atmospheric Environment 43, 6190-6198.

El Haddad, I., Marchand, N., Wortham, H., Piot, C., Besombes, J.-L., Cozic, J., Chauvel, C., Armengaud, A., Robin, D., Jaffrezo, J.-L., 2011a. Primary sources of PM2.5 particles in an industrial Mediterranean city, Marseille. Atmospheric Chemistry and Physics 11, 2039-2058. http://dx.doi.org/10.5194/acp-11-20392011.

El Haddad, I., Marchand, N., Temime-Roussel, B., Wortham, H., Piot, C., Besombes, J.L., Baduel, C., Voisin, D., Armengaud, A., Jaffrezo, J.-L., 2011b. Insights into the secondary fraction of the organic aerosol in a Mediterranean urban area: Marseille. Atmospheric Chemistry and Physics 11, 2059-2079. http:// dx.doi.org/10.5194/acp-11-2059-2011.

El Haddad, I., D’Anna, B., Temime-Roussel, B., Nicolas, M., Boreave, A., Favez, O. Voisin, D., Sciare, J., George, C., Jaffrezo, J.-L., Wortham, H., Marchand, N., 2012. On the chemical nature of the oxygenated organic aerosol: implication in the formation and aging of $\alpha$-pinene SOA in a Mediterranean environment, Marseille. Atmospheric Chemistry and Physics Discussion 12, 19769-19797. http:// dx.doi.org/10.5194/acpd-12-19769-2012.
Favez, O., El Haddad, I., Piot, C., Boreave, A., Abidi, E., Marchand, N., Jaffrezo, J.-L., Besombes, J.-L., Personnaz, M.-B., Sciare, J., Wortham, H., George, C., D’Anna, B., 2010. Inter-comparison of source apportionment models for the estimation of wood burning aerosols during wintertime in an Alpine city (Grenoble, France). Atmospheric Chemistry and Physics 10, 5295-5314. http://dx.doi.org/10.5194/ acp-10-5295-2010.

Farmer, D.K., Matsunaga, A., Docherty, K.S., Surratt, J.D., Seinfeld, J.H., Ziemann, P.J., Jimenez, J.L., 2010. Response of the Aerosol Mass Spectrometer to organonitrates and organosulfates and implications for field studies. Proceedings of the National Academy of Sciences of the United States of America 107, 66706675. http://dx.doi.org/10.1073/pnas.0912340107.

Fine, P.M., Cass, G.R., Simoneit, B.R.T., 2002. Chemical characterization of fine particle emissions from the fireplace combustion of woods grown in the southern United States. Environmental Science and Technology 36, 1442-1451.

Hallquist, M., Wenger, J.C., Baltensperger, U., Rudich, Y., Simpson, D., Claeys, M., Dommen, J., Donahue, N.M., George, C., Goldstein, A.H., Hamilton, J.F., Herrmann, H., Hoffmann, T., Iinuma, Y., Jang, M., Jenkin, M.E., Jimenez, J.L., Kiendler-Scharr, A., Maenhaut, W., McFiggans, G., Mentel, Th. F., Monod, A., Prévôt, A.S.H., Seinfeld, J.H., Surratt, J.D., Szmigielski, R., Wildt, J., 2009. The formation, properties and impact of secondary organic aerosol: current and emerging issues. Atmospheric Chemistry and Physics 9, 5155-5236. http:// dx.doi.org/10.5194/acp-9-5155-2009.

Heald, C.L., Kroll, J.H., Jimenez, J.L., Docherty, K.S., DeCarlo, P.F., Aiken, A.C., Chen, Q., Martin, S.T., Farmer, D.K., Artaxo, P., 2010. A simplified description of the evolution of organic aerosol composition in the atmosphere. Geophysical Research Letters 37, L08803. http://dx.doi.org/10.1029/2010GL042737.

Heeb, N.V., Schmid, P., Kohler, M., Gujer, E., Zennegg, M., Wenger, D., Wichser, A., Ulrich, A., Gfeller, U., Honegger, P., Zeyer, K., Emmenegger, L., Petermann, J.-L., Czerwinski, J., Mosimann, T., Kasper, M., Mayer, A., 2008. Secondary effects of catalytic diesel particulate filters: conversion of PAHs versus formation of nitroPAHs. Environmental Science and Technology 42, 3773-3779. http://dx.doi.org/ 10.1021/es7026949.

Iinuma, Y., Böge, O., Gräfe, R., Herrmann, H., 2010. Methyl-nitrocatechols: atmospheric tracer compounds for biomass burning secondary organic aerosols. Environmental Science and Technology 44, 8453-8459. http://dx.doi.org/ 10.1021/es102938a.

Jimenez, J.L., Canagaratna, M.R., Donahue, N.M., Prevot, A.S.H., Zhang, O., Kroll, J.H., DeCarlo, P.F., Allan, J.D., Coe, H., Ng, N.L., Aiken, A.C., Docherty, K.S., Ulbrich, I.M., Grieshop, A.P., Robinson, A.L., Duplissy, J., Smith, J.D., Wilson, K.R., Lanz, V.A., Hueglin, C., Sun, Y.L., Tian, J., Laaksonen, A., Raatikainen, T., Rautiainen, J., Vaattovaara, P., Ehn, M., Kulmala, M., Tomlinson, J.M., Collins, D.R., Cubison, M.J., Dunlea, E.J., Huffman, J.A., Onasch, T.B., Alfarra, M.R., Williams, P.I., Bower, K., Kondo, Y., Schneider, J., Drewnick, F., Borrmann, S., Weimer, S., Demerjian, K., Salcedo, D., Cottrell, L., Griffin, R., Takami, A., Miyoshi, T., Hatakeyama, S., Shimono, A., Sun, J.Y., Zhang, Y.M., Dzepina, K., Kimmel, J.R., Sueper, D. Jayne, J.T., Herndon, S.C., Trimborn, A.M., Williams, L.R., Wood, E.C., Middlebrook, A.M., Kolb, C.E., Baltensperger, U., Worsnop, D.R., 2009. Evolution of organic aerosols in the atmosphere. Science 326, 1525-1529.

Kautzman, K.E., Surratt, J.D., Chan, M.N., Chan, A.W.H., Hersey, S.P., Chhabra, P.S., Dalleska, N.F., Wennberg, P.O., Flagan, R.C., Seinfeld, J.H., 2010. Chemical composition of gas- and aerosol-phase products from the photooxidation of naphthalene. Journal of Physical Chemistry A 114, 913-934.

Kroll, J.H., Seinfeld, J.H., 2008. Chemistry of secondary organic aerosol: formation and evolution of low-volatility organics in the atmosphere. Atmospheric Environment 16, 3593-3624.

Kroll, J.H., Smith, J.D., Che, D.L., Kessler, S.H., Worsnop, D.R., Wilson, K.R., 2009. Measurement of fragmentation and functionalization pathways in the heterogeneous oxidation of oxidized organic aerosol. Physical Chemistry Chemical Physics 11, 8005-8014. http://dx.doi.org/10.1039/b905289e.

Liu, S., Takahama, S., Russell, L.M., Gilardoni, S., Baumgardner, D., 2009. Oxygenated organic functional groups and their sources in single and submicron organic particles in MILAGRO 2006 campaign. Atmospheric Chemistry and Physics 9, 6849-6863. http://dx.doi.org/10.5194/acp-9-6849-2009.

Mertes, P., Pfaffenberger, L., Dommen, J., Kalberer, M., Baltensperger, U., 2012. Development of a sensitive long pathlength absorbance photometer to quantify peroxides in aerosol particles (Peroxide-LOPAP). Atmospheric Measurement Techniques Discussion 5, 1431-1457. http://dx.doi.org/10.5194/amtd-5-14312012.

Ng, N.L., Canagaratna, M.R., Zhang, Q., Jimenez, J.L., Tian, J., Ulbrich, I.M., Kroll, J.H., Docherty, K.S., Chhabra, P.S., Bahreini, R., Murphy, S.M., Seinfeld, J.H., Hildebrandt, L., Donahue, N.M., DeCarlo, P.F., Lanz, V.A., Prévôt, A.S.H., Dinar, E., Rudich, Y., Worsnop, D.R., 2010. Organic aerosol components observed in Northern Hemispheric datasets from Aerosol Mass Spectrometry. Atmospheric Chemistry and Physics 10, 4625-4641. http://dx.doi.org/10.5194/acp-10-46252010.

Ng, N.L., Canagaratna, M.R., Jimenez, J.L., Chhabra, P.S., Seinfeld, J.H., Worsnop, D.R., 2011. Changes in organic aerosol composition with aging inferred from aerosol mass spectra. Atmospheric Chemistry and Physics 11, 6465-6474. http:// dx.doi.org/10.5194/acp-11-6465-2011.

Russell, L.M., Bahadura, R., Ziemann, P., 2011. Identifying organic aerosol sources by comparing functional group composition in chamber and atmospheric particles. Proceedings of the National Academy of Sciences of the United States of America 108, 3516-3521. http://dx.doi.org/10.1073/pnas.1006461108.

Schwartz, R.E., Russell, L.M., Sjostedt, S.J., Vlasenko, A., Slowik, J.G., Abbatt, J.P.D., Macdonald, A.M., Li, S.M., Liggio, J., Toom-Sauntry, D., Leaitch, W.R., 2010. 
Biogenic oxidized organic functional groups in aerosol particles from a mountain forest site and their similarities to laboratory chamber products. Atmospheric Chemistry and Physics 10, 5075-5088. http://dx.doi.org/10.5194/acp10-5075-2010.

Stone, E.A., Hedman, C.J., Sheesley, R.J., Shafer, M.M., Schauer, J.J., 2009. Investigating the chemical nature of humic-like substances (HULIS) in North American atmospheric aerosols by liquid chromatography tandem mass spectrometry. Atmospheric Environment 43, 4205-4213.

Surratt, J.D., Murphy, S.M., Kroll, J.H., Ng, N.L., Hildebrandt, L., Sorooshian, A Szmigielski, R., Vermeylen, R., Maenhaut, W., Claeys, M., Flagan, R.C., Seinfeld, J.H., 2006. Chemical composition of secondary organic aerosol formed from the photooxidation of isoprene. Journal of Physical Chemistry A 31, 9665-9690.

Tagliavini, E., Moretti, F., Decesari, S., Facchini, M.C., Fuzzi, S., Maenhaut, W., 2006 Functional group analysis by H-NMR/chemical derivatization for the characterization of organic aerosol from the SMOCC field campaign. Atmospheric Chemistry and Physics 6, 1003-1019. http://dx.doi.org/10.5194/acp-6-1003-2006.

Valorso, R., Aumont, B., Camredon, M., Raventos-Duran, T., Mouchel-Vallon, C. Ng, N.L., Seinfeld, J.H., Lee-Taylor, J., Madronich, S., 2011. Explicit modelling of SOA formation from $\alpha$-pinene photooxidation: sensitivity to vapour pressure estimation. Atmospheric Chemistry and Physics 11, 6895-6910. http:// dx.doi.org/10.5194/acp-11-6895-2011. 